\title{
Solvent-Free Synthesis of New Coumarins
}

\author{
Redah I. Al-Bayati, ${ }^{1}$ Mahdi F. Radey, ${ }^{1}$ and Ahmed A. Al-Amiery ${ }^{2,3}$ \\ ${ }^{1}$ Chemistry Department, College of Science, Al-Mustansiriyah University, Baghdad 66004, Iraq \\ ${ }^{2}$ Applied Chemical Division, Department of Applied Science, University of Technology, Baghdad 10066, Iraq \\ ${ }^{3}$ Department of Chemical and Processing Engineering, Faculty of Engineering and Built Environment, \\ University of Kebangsaan Malaysia, Selangor, Bangi 43600, Malaysia
}

Correspondence should be addressed to Ahmed A. Al-Amiery, dr.ahmed1975@gmail.com

Received 26 March 2012; Accepted 4 June 2012

Academic Editor: Robert Salomon

Copyright (c) 2012 Redah I. Al-Bayati et al. This is an open access article distributed under the Creative Commons Attribution License, which permits unrestricted use, distribution, and reproduction in any medium, provided the original work is properly cited.

A solvent-free synthesis of five series of coumarin derivatives using microwave assistant is presented herein. The synthesized compounds are fully characterized by UV-VIS, FT-IR, and NMR spectroscopy.

\section{Introduction}

Coumarin (2H-Lbenzopyran-2-one) and its derivatives possess a wide range of various biological and pharmaceutical activities. They have a wide range of applications as antitumor $[1,2]$, anti-HIV $[3,4]$, anticoagulant $[5,6]$, antimicrobial $[7,8]$, antioxidant $[9,10]$, and anti-inflammatory $[11$, 12] agents. The antitumor activities of coumarin compounds have been extensively examined [13-16]. Although most of the existing natural coumarins have been isolated from higher plants, some of them have been discovered in microorganisms, for example, aminocoumarin antibiotics: novobiocin, coumermycin A1, and chlorobiocin (produced by the actinomycete Streptomyces niveus) [17]. Synthetic coumarin derivatives have been obtained by chemical modification of the coumarin ring. Recently, density functional theory (DFT) has been accepted by the quantum chemistry community as a cost-effective approach for the computation of molecular structure, vibration frequencies, and energies of chemical reactions. Many studies have shown that the molecular structures and vibration frequencies calculated by DFT methods are more reliable than MP2 methods [18-26]. While there is sufficient evidence that DFT provides accurate description of the electronic and structural properties of solids, interfaces, and small molecules, relatively little is known about the symmetric performance of DFT applications to their molecular associates.
Structure activity relationships of coumarin derivatives have revealed that the presence of substituted amino derivatives is an essential feature of their pharmacological action. Based on these findings, we try to describe the synthesis of some compounds featuring different heterocyclic rings fused onto the coumarin moiety with the aim of obtaining more potent pharmacologically active compounds.

\section{Experimental}

2.1. General. The chemicals used for the synthesis were supplied by Sigma-Aldrich. Purity of the compounds was checked on thin layer chromatography (TLC) plates (Silica Gel G) using the solvent systems benzene-ethyl acetatemethanol $(40: 30: 30, \mathrm{v} / \mathrm{v} / \mathrm{v})$ and toluene-acetone $(75: 25$, $\mathrm{v} / \mathrm{v}$ ). The spots were located under UV light (254 and $365 \mathrm{~nm}$ ). Melting points were determined on GallenKamp (MFB-600) melting point apparatus and were uncorrected. The IR spectra of the compounds were recorded on a shimadzu FT-IR-8300 spectrometer as KBr disk. The UV-VIS spectra were performed on Cintra-5-Gbes scientific equipment. The ${ }^{1} \mathrm{H}$-NMR and ${ }^{13} \mathrm{C}-\mathrm{NMR}$ spectra (solvent DMSOd6) were recorded on Bruker $400 \mathrm{MHz}$ spectrophotometer using TMS as internal standard.

2.2. Synthesis of 1-aminoquinolin-2(1H)-one (1). 1-aminoquinolin-2(1H)-one (1) was synthesized according to [27], 
and the structure of the compound was confirmed with elemental analyses and spectral analyses (IR, UV-VIS, ${ }^{1} \mathrm{H}-$ NMR, and ${ }^{13} \mathrm{C}-\mathrm{NMR}$ ).

2.3. Synthesis of (E)-1-((2-hydroxybenzylidene)amino)quinolin-2(1H)-one (2) and (E)-1-((1-(thiophen-2-yl)ethylidene) amino)quinolin-2(1H)-one (3). $\mathrm{N}$-aminocoumarin $(0.16 \mathrm{~g}$, $0.001 \mathrm{~mol}$ ) and 2-hydroxybenzaldehyde (or 1-(thiophen-2yl)ethanone) $(0.001 \mathrm{~mol})$ were placed together in an open small test tube; after 6 minutes, the product was separated out and recrystallized.

2.4. Synthesis of $1,1^{\prime}-\left(\left(1 Z, 1^{\prime} Z\right)-(1,4-p h e n y l e n e b i s(m e t h a n y-\right.$ lylidene))bis(azanylylidene))bis(quinolin-2(1H)-one) (4). Naminocoumarin $(0.32 \mathrm{~g}, 0.002 \mathrm{~mol})$ and terephthaldehyde $(0.134 \mathrm{~g}, 0.001 \mathrm{~mol})$ were placed together in an open small test tube; after 8 minutes, the product was separated out and recrystallized.

2.5. Synthesis of 2-(2-oxoquinolin-1(2H)-yl)isoindoline-1,3dione (5) and 3-methylene-1-(2-oxoquinolin-1(2H)-yl)pyrrolidine-2,5-dione (6). $\mathrm{N}$-aminocoumarin $(0.16 \mathrm{~g}, 0.001 \mathrm{~mol})$ and phthalic anhydride (or itaconic anhydride) $(0.001 \mathrm{~mol})$ were placed together in an open small test tube; after 5 minutes, the product was separated out and recrystallized.

2.6. Synthesis of 1-(naphthalen-1-yl)-3-(2-oxoquinolin-1(2H)yl) urea (7). $\mathrm{N}$-aminocoumarin $(0.16 \mathrm{~g}, 0.001 \mathrm{~mol})$ and 1 naphthylisocyanate $(0.17 \mathrm{~g}, 0.001 \mathrm{~mol})$ were placed together in an open small test tube; after 8 minutes, the product was separated out and recrystallized.

2.7. Synthesis of 1,1'-(hexane-1,6-diyl)bis(3-(2-oxoquinolin-1(2H)-yl)urea) (8) and 1,1'-(2-methyl-1,4-phenylene)bis (3-(2-oxoquinolin-1(2H)-yl)urea) (9). N-aminocoumarin $(0.32 \mathrm{~g}, 0.002 \mathrm{~mol})$ and hexamethylene diisocyanate (or toluene-2,5-diisocyanate) $(0.001 \mathrm{~mol})$ were placed together in an open small test tube; after 8 minutes, the product was separated out and recrystallized.

2.8. Synthesis of 2-((2-oxoquinolin-1(2H)-yl)amino)thiazol5(4H)-one (10), 2-(carboxy (2-oxoquinolin-1(2H)-yl)amino) acetic acid (11) and 1-(pyridin-2-ylamino)quinolin-2(1H)one. $\mathrm{N}$-aminocoumarin $(0.16 \mathrm{~g}, 0.001 \mathrm{~mol})$ and rhodanine (or 2-mercaptopyridine or 2-mercaptosuccinic acid) $(0.001 \mathrm{~mol})$ were placed together in an open small test tube; after 8 minutes, the product was separated out and recrystallized.

2.9. Synthesis of 3H-[1,2,4,5]tetrazino[1,6-a]quinolin-2amine (13). N-aminocoumarin $(0.16 \mathrm{~g}, 0.001 \mathrm{~mol})$ and thiosemicarbazide $(0.1 \mathrm{~g}, 0.001 \mathrm{~mol})$ were placed together in an open small test tube; after 10 minutes, the product was separated out and recrystallized.

2.10. The Calculation Method. Gaussian 03, Revision C.01 [28] was used for the calculation of ground-state geometry

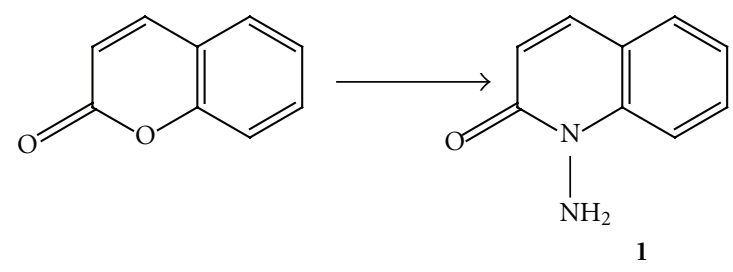

Scheme 1

which was optimized to a local minimum without any symmetry restrictions using basis set 3-21G $[29,30]$. The Becke three-parameter hybrid (B3) [31, 32] exchange functional in combination with the Lee-Yang-Parr (LYP) [33] correction functional (B3LYP) was used for all geometry optimizations, thermodynamic functions at conditions $($ temperature $=298.150$ Kelvin and pressure $=1.0 \mathrm{Atm})$, high occupied molecular orbital (HOMO), and low unoccupied molecular orbital (LUMO) distribution, and some physical properties for compound 3.

\section{Results and Discussion}

3.1. Chemistry. For the synthesis of new coumarin derivatives, the reaction sequences outlined in Schemes 1, 2, 3, 4, $5,6,7$, and 8 were followed. We started from coumarin (1) which is commercially available or, alternatively, readily accessible through a Pechmann and Perkin condensation [25]. Recrystallization solvent was chloroform. Yield 91\%; M.P. $131-133^{\circ} \mathrm{C}$. The structure of compound (1) was confirmed from its spectral data. UV-VIS in methanol, $\lambda_{\max } \mathrm{nm}$ : 280 (0.93) and 227 (1.8). The IR spectrum showed two strong absorption bands at 3290 to $3300 \mathrm{~cm}^{-1}$ and strong band at $1645 \mathrm{~cm}^{-1}$, corresponding to $-\mathrm{NH}_{2}$ and $-\mathrm{C}=\mathrm{O}$, respectively; 1595 (C=C aromatic), 3045 (C-H aromatic), $1242(\mathrm{C}-\mathrm{N})$. ${ }^{1} \mathrm{H}-\mathrm{NMR}: 4.1\left(\mathrm{~s}, 2 \mathrm{H},-\mathrm{NH}_{2}\right), 6.7(\mathrm{t}, \mathrm{Ar}-\mathrm{H}), 7.4(\mathrm{~d}, \mathrm{Ar}-\mathrm{H})$ and $7.1(\mathrm{~d}, \mathrm{Ar}-\mathrm{H}) .{ }^{13} \mathrm{C}-\mathrm{NMR}: 126,127,127.8,128,123.3,128.5$, 129, 155 and 157.

3.1.1. Compound (2). Yellow solid; Yield $92 ; \mathrm{mp} 86-88^{\circ} \mathrm{C}$; IR $(\mathrm{KBr})\left(/ \mathrm{cm}^{-1}\right): 3076,2945,2920,1681,1653,1583,1520$. ${ }^{1} \mathrm{H}$ NMR $\left(300 \mathrm{MHz}, \mathrm{CDCl}_{3}\right)$ : (ppm) $2.3\left(\mathrm{~s}, 3 \mathrm{H},-\mathrm{CH}_{3}\right), 7.1-$ 7.9 (9H, Ar-H); ${ }^{13} \mathrm{C} \mathrm{NMR}\left(125 \mathrm{MHz}, \mathrm{CDCl}_{3}\right)$ : (ppm) 15, 23, 126, 128, 128.2, 129, 129.8, 130, 131, 133, 135, 143, 144, 157.

3.1.2. Compound (3). Yellow solid; Yield $88 ; \mathrm{mp} 215-217^{\circ} \mathrm{C}$; IR $(\mathrm{KBr})\left(/ \mathrm{cm}^{-1}\right): 3200,3046,1681,1621,1573,1487 .{ }^{1} \mathrm{H}$ $\operatorname{NMR}\left(300 \mathrm{MHz}, \mathrm{CDCl}_{3}\right):(\mathrm{ppm}) 3.3(\mathrm{~s}, 1 \mathrm{H},-\mathrm{OH}), 9.0$ (s, $1 \mathrm{H}, \mathrm{N}=\mathrm{CH}), 6.6-7.7 ;{ }^{13} \mathrm{C}$ NMR $\left(125 \mathrm{MHz}, \mathrm{CDCl}_{3}\right):(\mathrm{ppm})$ $17.6,118.7,125.0,125.5,125.9,127.4,128.2,136.5,137.1$, 139.0, 161.3, 164.6.

3.1.3. Compound (4). Yellow solid; Yield 78 ; $\mathrm{mp} 230-232^{\circ} \mathrm{C}$; IR $(\mathrm{KBr})\left(/ \mathrm{cm}^{-1}\right): 3070,1670,1604,1595,1456 .{ }^{1} \mathrm{H}$ NMR $\left(300 \mathrm{MHz}, \mathrm{CDCl}_{3}\right):(\mathrm{ppm}) 6.1(\mathrm{dd}, 1 \mathrm{H},=\mathrm{CH}), 7.1-7.6(\mathrm{~m}$, $1 \mathrm{H}, \mathrm{Ar}-\mathrm{H}), 7.9-8.2(\mathrm{~m}, 1 \mathrm{H}, \mathrm{Ar}-\mathrm{H}) ;{ }^{13} \mathrm{C}$ NMR $(125 \mathrm{MHz}$, $\left.\mathrm{CDCl}_{3}\right)$ : (ppm) 117.5, 126.0, 126.6, 128.3, 128.7, 131.2, $131.4,131.9,133.0,137.5,141.9,159.3$. 

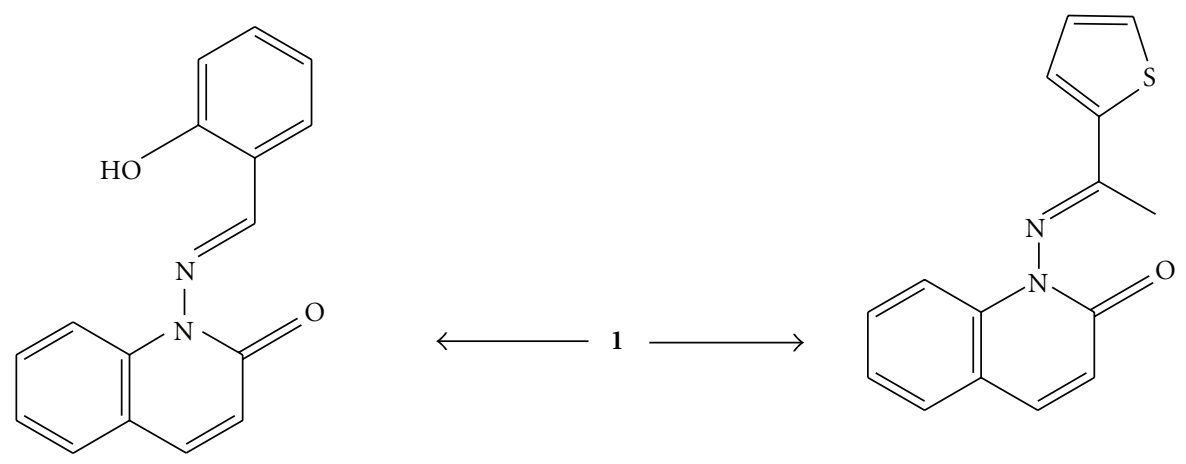

Scheme 2

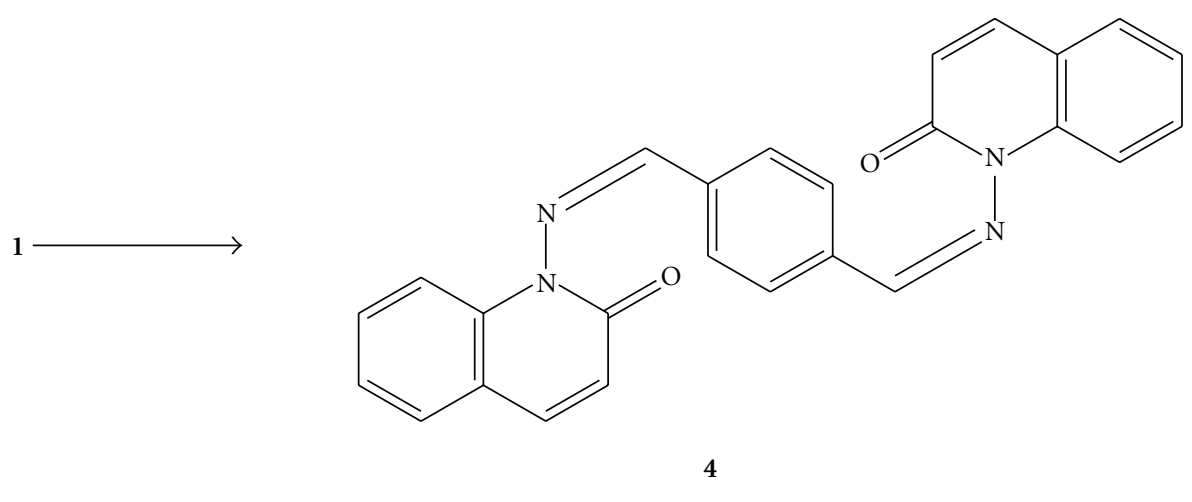

Scheme 3
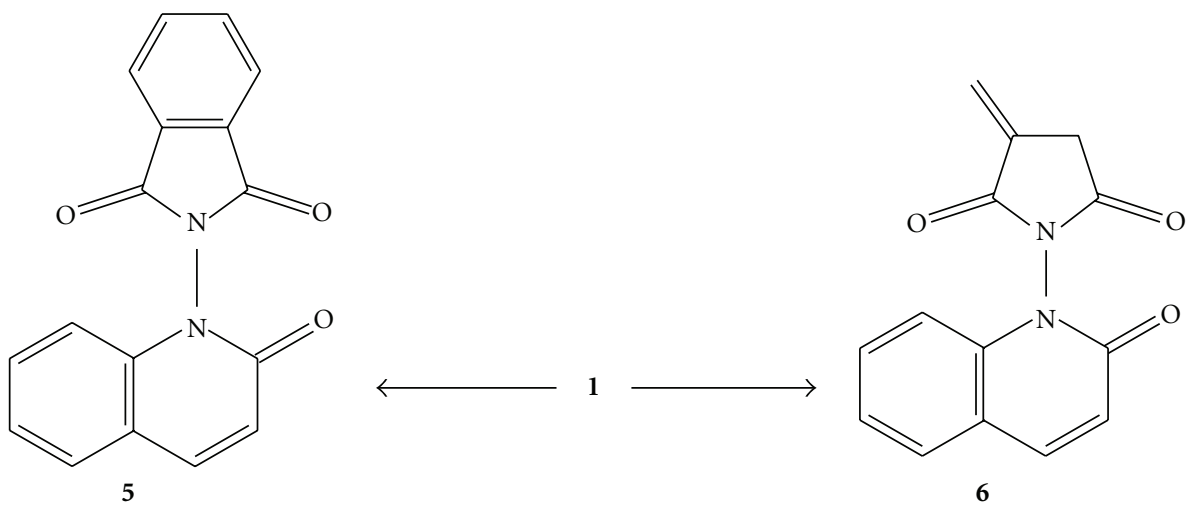

SCHEMe 4

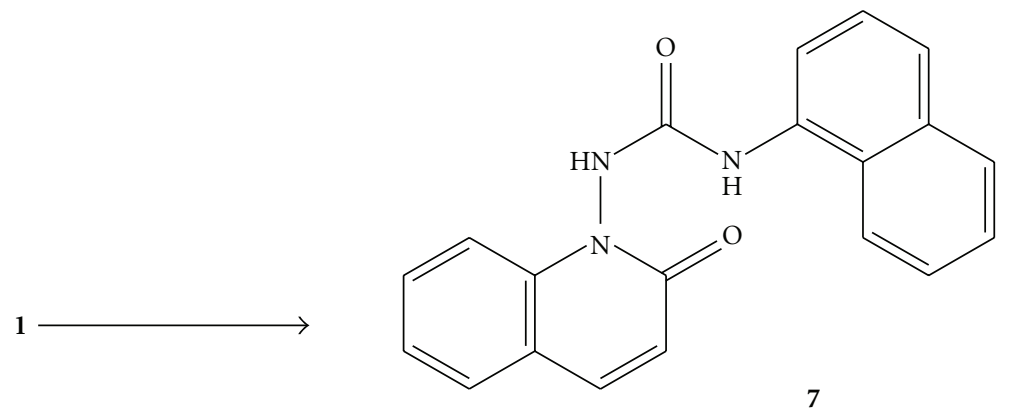

SCHeme 5 

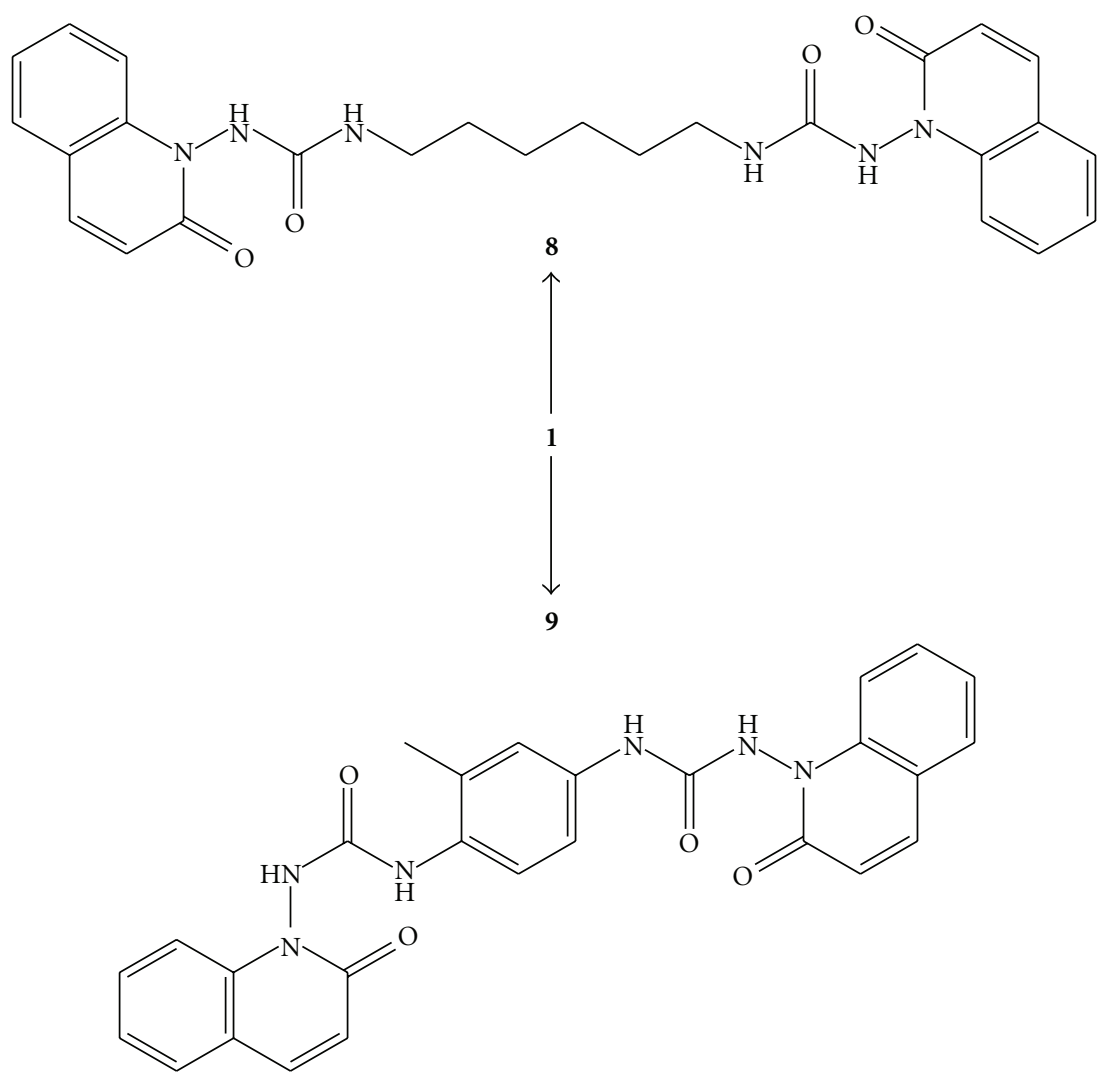

Scheme 6
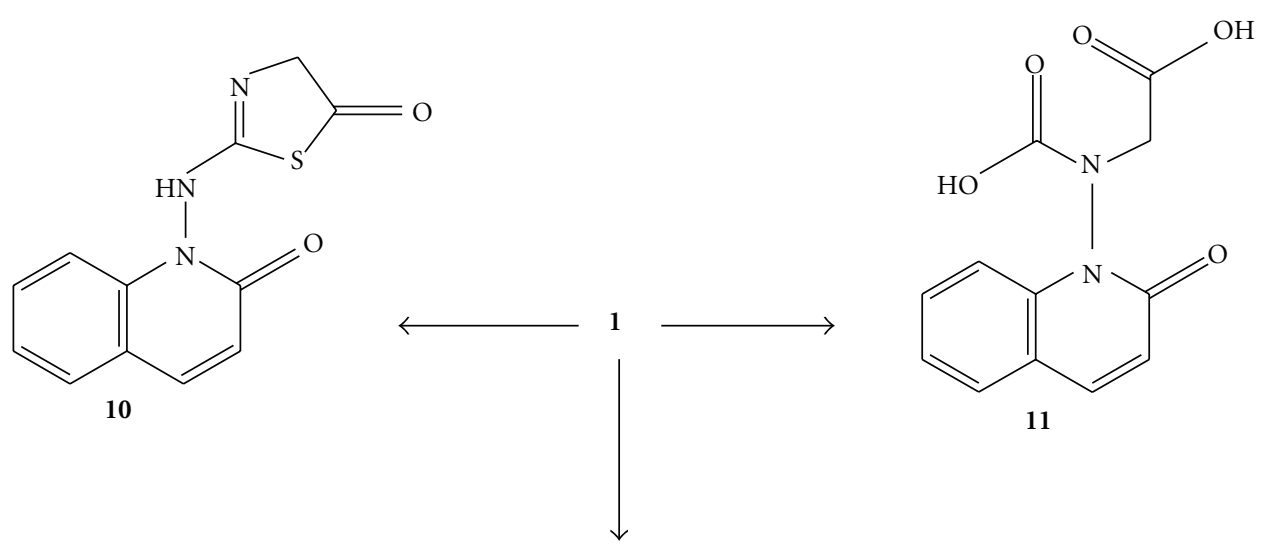<smiles>O=c1ccc2ccccc2n1Nc1ccccn1</smiles>

Scheme 7 
TABLE 1: Total energy, relative energies and heat of formation for 3.

\begin{tabular}{lccr}
\hline Compound & Potential energy & Total energy & Kinetic energy \\
\hline 3 & $-1445030.1135 \mathrm{Kcal} / \mathrm{Mol}$ & $-724778.6338 \mathrm{Kcal} / \mathrm{Mol}$ & $720251.4797 \mathrm{Kcal} / \mathrm{Mol}$ \\
\hline
\end{tabular}

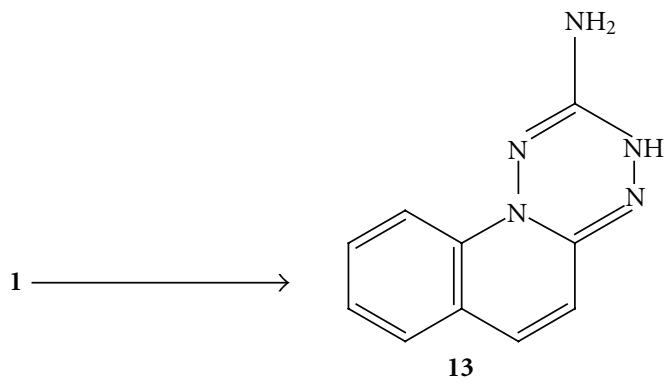

SCHEMe 8
$31.9,37.0,117.6,122.4,122.8,124.1,124.4,125.2,141.3$, 143.0, 158.6.

3.1.9. Compound (10). Yellow Yield 93; oily; IR ( $\mathrm{KBr})$ (/ $\left.\mathrm{cm}^{-1}\right): 3182(\mathrm{~N}-\mathrm{H}), 3072(\mathrm{C}-\mathrm{H}$ Aromatic), $1668(\mathrm{C}=\mathrm{O})$, 1598 and $1456\left(\mathrm{C}=\mathrm{C}\right.$ arom), $1573(\mathrm{C}=\mathrm{N}) .{ }^{1} \mathrm{H}$ NMR $\left(300 \mathrm{MHz}, \mathrm{CDCl}_{3}\right)$ : (ppm) $3.6\left(\mathrm{~s}, 2 \mathrm{H},-\mathrm{CH}_{2}\right), 5.8(\mathrm{~d}, 1 \mathrm{H}$, $=\mathrm{C}-\mathrm{H}), 6.4(\mathrm{~d}, 1 \mathrm{H},=\mathrm{C}-\mathrm{H}), 7.0-7.3(1 \mathrm{H}, \mathrm{Ar}-\mathrm{H}) ;{ }^{13} \mathrm{C}$ NMR $\left(125 \mathrm{MHz} \mathrm{CDCl}_{3}\right)$ : (ppm) 41.0, 111.6, 119.1, 122.3, 122.6, $122.9,125.3,146.8,151.1,152.9,156.1$.

3.1.10. Compound (11). Yellow solid; Yield 90; $\mathrm{mp} \mathrm{102-}$ $104^{\circ} \mathrm{C}$; IR $(\mathrm{KBr})\left(/ \mathrm{cm}^{-1}\right): 3182,3070,1708,1570 .{ }^{1} \mathrm{H}$ NMR $\left(300 \mathrm{MHz} \mathrm{CDCl}_{3}\right)$ : (ppm) $3.8\left(\mathrm{~s}, 2 \mathrm{H}, \mathrm{CH}_{2}\right), 5.9(\mathrm{dd}, 1 \mathrm{H}$, $=\mathrm{C}-\mathrm{H}), 6.6(\mathrm{~d}, 1 \mathrm{H},=\mathrm{C}-\mathrm{H}), 6.9-7.2(1 \mathrm{H}, \mathrm{Ar}-\mathrm{H}) ;{ }^{13} \mathrm{C}$ NMR $\left(125 \mathrm{MHz} \mathrm{CDCl}_{3}\right)$ : (ppm) 42.7, 117.4, 120.1, 121.9, 122.1, $122.4,122.8,15.3,127.8,151.4,158.5,161.4,168.8$.

3.1.11. Compound (12). Yellow oily; Yield 90; IR ( $\mathrm{KBr})$ $\left(/ \mathrm{cm}^{-1}\right)$ : $3217(\mathrm{~N}-\mathrm{H}), 3180-2563(\mathrm{OH}), 2945,2920,1714$, 1651, 1568, 1462. ${ }^{1} \mathrm{H}$ NMR $\left(300 \mathrm{MHz}, \mathrm{CDCl}_{3}\right)$ : (ppm) 5.2 $(\mathrm{s}, 1 \mathrm{H},-\mathrm{NH}), 6.1(\mathrm{~d}, 1 \mathrm{H},=\mathrm{C}-\mathrm{H}), 6.4(\mathrm{~d}, 1 \mathrm{H},=\mathrm{C}-\mathrm{H}), 7.0-$ $7.2(\mathrm{~m}, 1 \mathrm{H}, \mathrm{Ar}-\mathrm{H}), 7.3-7.5(\mathrm{~m}, 1 \mathrm{H}, \mathrm{Ar}-\mathrm{H}) ;{ }^{13} \mathrm{C} \mathrm{NMR}$ $\left(125 \mathrm{MHz}, \mathrm{CDCl}_{3}\right)$ : (ppm) 117.9, 118.4, 120.4, 121.1, 121.4, $122.5,137.9,145.0,152.1,155.9,171.0,171.7$.

3.1.12. Compound (13). Yellow solid; Yield 87; solid; mp 92-94 ${ }^{\circ} \mathrm{C}$; IR $(\mathrm{KBr})\left(/ \mathrm{cm}^{-1}\right)$ : 3254 and $3147(\mathrm{~N}-\mathrm{H}), 3003$, 2676, 1622, 1577, 1556. ${ }^{1} \mathrm{H}$ NMR (300 MHz, $\left.\mathrm{CDCl}_{3}\right)$ : (ppm) $5.9(1 \mathrm{H}, \mathrm{s},=\mathrm{C}-\mathrm{H}), 6.4(1 \mathrm{H}, \mathrm{s},=\mathrm{C}-\mathrm{H}), 6.9(1 \mathrm{H}, \mathrm{dd}$, $-\mathrm{C}-\mathrm{H}$ aromatic), 7.3 (1H, dd, $-\mathrm{C}-\mathrm{H}$ aromatic); ${ }^{13} \mathrm{C} \mathrm{NMR}$ $\left(125 \mathrm{MHz}, \mathrm{CDCl}_{3}\right)$ : (ppm) 113.1, 117.0, 122.4, 127.6, 127.9, $133.1,136.1,140.5,140.8,157.2$.

\subsection{Computational Studies}

3.2.1. Atomic Charges (Mulliken Charges). An earlier study [34] has shown that atomic charges were affected by the presence of the substituent of rings. For compound 3 the $3 \mathrm{D}$ geometrical structure is given in Figure 1. The data obtained show that highest atomic charge in compound 3 is at $[\mathrm{N}(7)$ $-0.744890]$ followed by the next charge value at $[\mathrm{O}(11)-0$. 0. 500312]. These data show clearly that these atoms are the most reactive toward the addition, substitution reactions, and bonding with the metal. The determined bond angle and twist angle, stretch (1.9443), bend (7. 6317), stretch-bend (0. 0909), and the 3D geometrical structure indicate that this molecule is a nonplanar molecular and the stereochemistry

is [C(9): $\mathrm{C}(10):(\mathrm{Z})$; $\mathrm{N}(12)-\mathrm{C}(13):(\mathrm{Z})]$. $\left.2 \mathrm{H},-\mathrm{CH}_{2}\right), 3.1\left(\mathrm{~m}, 2 \mathrm{H},-\mathrm{CH}_{2}\right), 6.9-7.2(\mathrm{~m}, 1 \mathrm{H}, \mathrm{Ar}-\mathrm{H}) ; 7.3-$ 7.5(1H, Ar-H); ${ }^{13} \mathrm{C}$ NMR (125 MHz, $\left.\mathrm{CDCl}_{3}\right)$ : (ppm) 28.2,
3.1.8. Compound (9). White solid; Yield 88; mp $210-212^{\circ} \mathrm{C}$; IR (KBr) $\left(/ \mathrm{cm}^{-1}\right): 3307(\mathrm{~N}-\mathrm{H}), 3020$ (C-H Aromatic), 2926 and $2850(\mathrm{C}-\mathrm{H}$ ali.), 1670 and $1658(\mathrm{C}=\mathrm{O}), 1633$ and 1602 $\left(\mathrm{C}=\mathrm{C}\right.$ arom). ${ }^{1} \mathrm{H}$ NMR $\left(300 \mathrm{MHz}, \mathrm{CDCl}_{3}\right):(\mathrm{ppm}) 2.3(\mathrm{~m}$,

3.1.4. Compound (5). White solid; Yield 90; mp 340 dec. ${ }^{\circ} \mathrm{C}$; IR $(\mathrm{KBr})\left(/ \mathrm{cm}^{-1}\right): 3300(\mathrm{~N}-\mathrm{H}), 3095(\mathrm{C}-\mathrm{H}$ Aromatic), 2931, 2858 (C-H ali), 1664 (C=O), 1556, 1458 (C=C Aromatic). $6.3(\mathrm{~s}, 1 \mathrm{H},-\mathrm{NHCO}), 3.3\left(\mathrm{~s}, 2 \mathrm{H}, \mathrm{NHCH}_{2}\right), 6.9-7.5(6 \mathrm{H}, \mathrm{Ar}-$ $\mathrm{H}) ;{ }^{13} \mathrm{C} \mathrm{NMR}\left(125 \mathrm{MHz}, \mathrm{CDCl}_{3}\right)$ : (ppm) 111.8, 114.0, 114.3 $117.5,119.0,121.1,121.2,121.6,121.9,124.1,124.6,128.2$, $130.3,131.2,143.1,144.2,144.7,144.9,152.9,161.0$. 


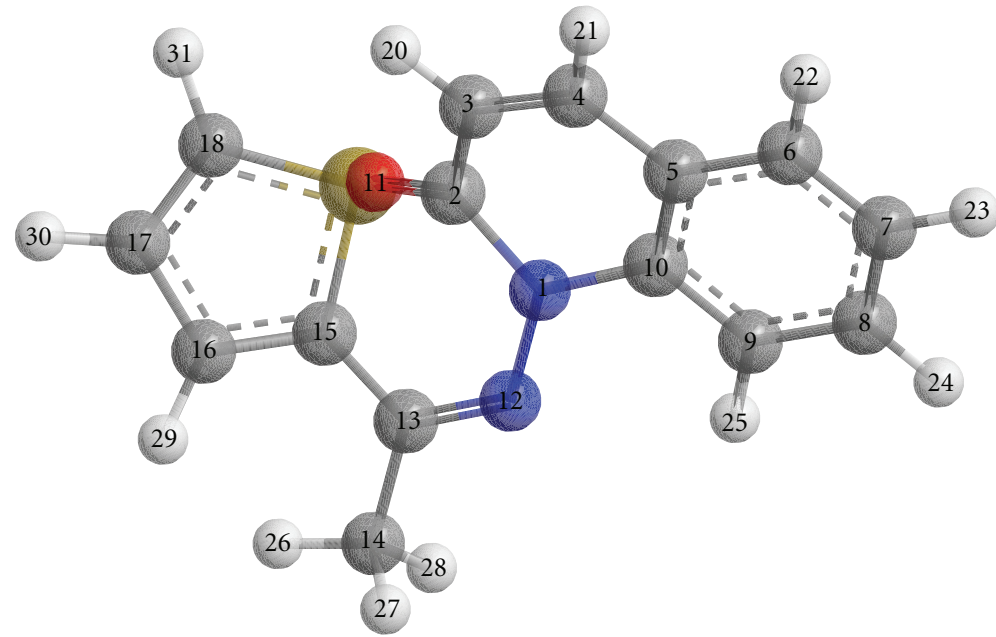

FIgURE 1: Optimized 3D geometrical structure for compound 3.

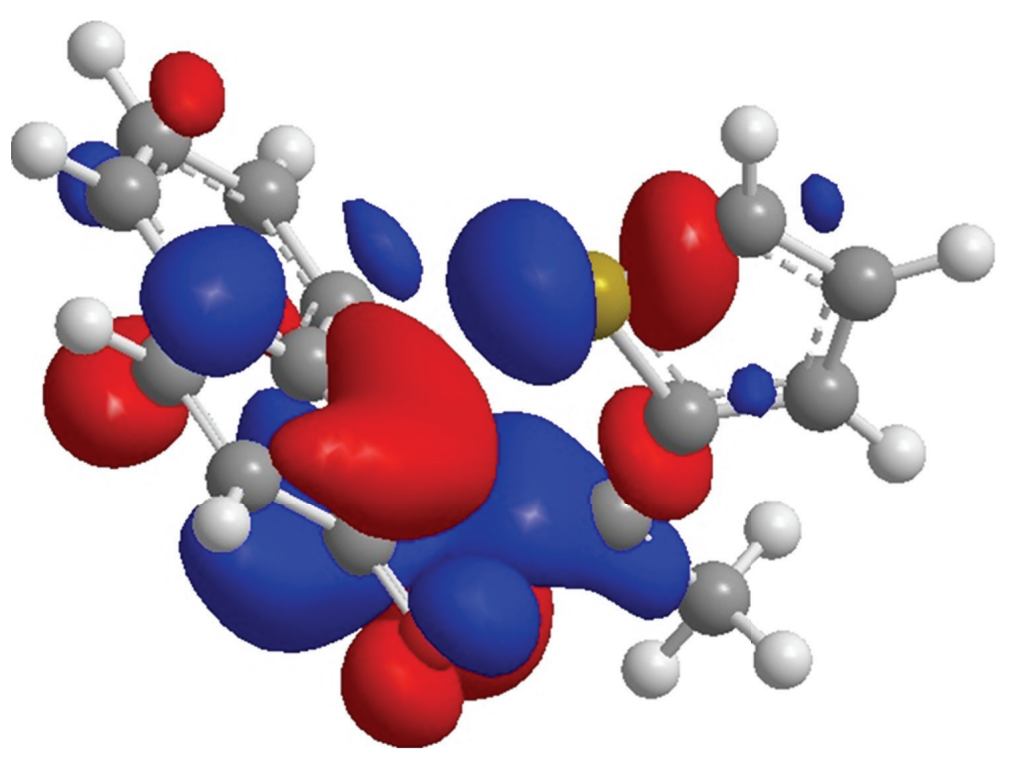

FIGURE 2: The highest occupied molecular orbital (HOMO) of compound 3.

3.2.2. Density Function Theory (DFT). DFT calculations were performed for compound 3. Optimized molecular structure of the most stable form is shown in Figure 1, Table 1; the calculated energies and relative energies are presented in Table 1. Molecular orbital calculations provide a detailed description of orbitals including spatial characteristics, nodal patterns, and individual atom contributions. The contour plots of the frontier orbitals for the ground state of compound 3 are shown in Figures 2 and 3, including the highest occupied molecular orbital (HOMO) and the lowest unoccupied molecular orbital (LUMO). It is interesting to see that both orbitals are substantially distributed over the conjugation plane. It can be seen from Figure 2 that the HOMO orbitals are located on the substituted molecule while LUMO orbitals resemble those obtained for the unsubstituted molecule, and therefore the substitution has an influence on the electron donation ability, but only a small impact on electron acceptance ability [35]. The orbital energy levels of HOMO and LUMO of compound 3 are listed in Table 2. It can be seen that the energy gaps between HOMO and LUMO are about $-5.419 \mathrm{eV}$. The lower value in the HOMO and LUMO energy gap explains the eventual charge transfer interaction taking place within the molecules. The dipole moments of compounds 3 were also calculated and listed in Table 3.

\section{Conclusions}

In this study, the new coumarins have been successively synthesized and characterized by using various spectroscopic 


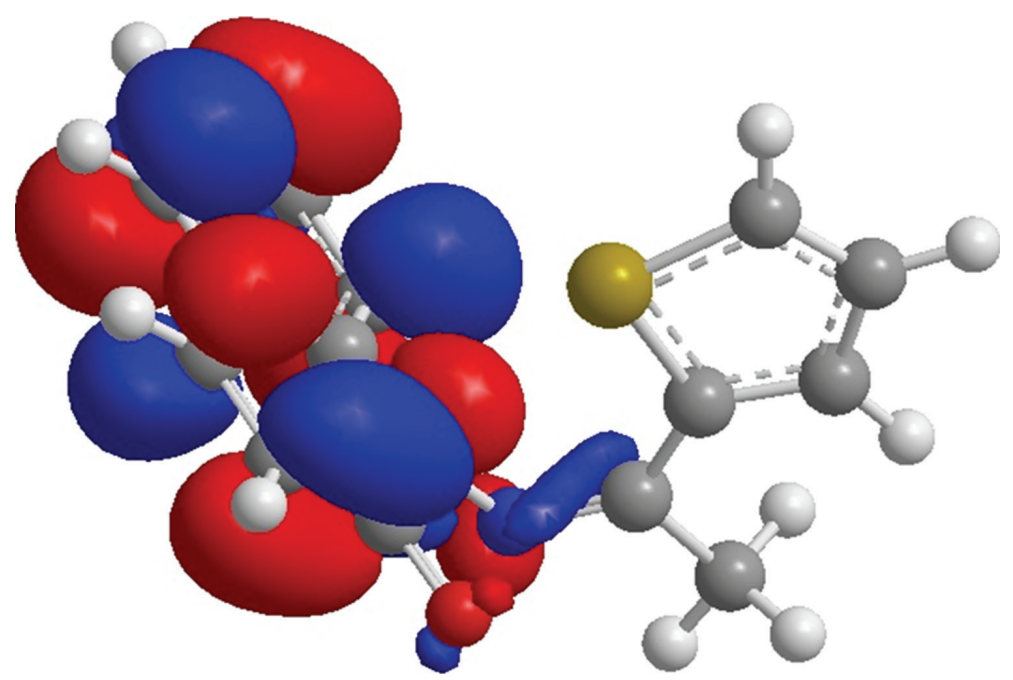

FIgURE 3: The lowest unoccupied molecular orbital (LUMO) of compound 3.

TABLE 2: HOMO and LUMO energies of 3.

\begin{tabular}{lccc}
\hline Compound & HOMO & LUMO & $\Delta E$ \\
\hline $\mathbf{3}$ & $-8.992 \mathrm{eV}$ & $-3.573 \mathrm{eV}$ & -4.390 \\
\hline
\end{tabular}

TABle 3: The dipole moments (Debye) of 3.

Compound $\mathrm{x}$-component $\mathrm{y}$-component $\mathrm{z}$-component Magnitude

\begin{tabular}{lllll}
\hline 3 & -0.984845 & 3.875375 & -1.511631 & 4.274749
\end{tabular}

methods. The synthesized compound 3 was studied theoretically, and the atomic charges, heat of formation, and stereochemistry were estimated, and it was found that compound 3 is not planar.

\section{References}

[1] H. Madari, D. Panda, L. Wilson, and R. S. Jacobs, "Dicoumarol: a unique microtubule stabilizing natural product that is synergistic with Taxol," Cancer Research, vol. 63, no. 6, pp. 1214-1220, 2003.

[2] I. Kostova, "Synthetic and natural coumarins as cytotoxic agents," Current Medicinal Chemistry, vol. 5, no. 1, pp. 29-46, 2005.

[3] Y. Takeuchi, L. Xie, L. M. Cosentino, and K. H. Lee, "Anti-AIDS agents-XXVIII. ${ }^{1}$ Synthesis and Anti-HIV activity of methoxy substituted 3',4'-Di-O-(-)-camphanoyl-(+)-ciskhellactone (DCK) analogues," Bioorganic \& Medicinal Chemistry Letters, vol. 7, no. 20, pp. 2573-2578, 1997.

[4] Y. Shikishima, Y. Takaishi, G. Honda et al., "Chemical constituents of Prangos tschimganica; structure elucidation and absolute configuration of coumarin and furanocoumarin derivatives with anti-HIV activity," Chemical and Pharmaceutical Bulletin, vol. 49, no. 7, pp. 877-880, 2001.

[5] I. Manolov, C. Maichle-Moessmer, and N. Danchev, "Synthesis, structure, toxicological and pharmacological investigations of 4-hydroxycoumarin derivatives," European Journal of Medicinal Chemistry, vol. 41, no. 7, pp. 882-890, 2006.
[6] J. C. Jung, J. C. Kim, and O. S. Park, "Simple and cost effective syntheses of 4-hydroxycoumarin," Synthetic Communications, vol. 29, no. 20, pp. 3587-3595, 1999.

[7] D. A. Ostrov, J. A. Hernández Prada, P. E. Corsino, K. A. Finton, N. Le, and T. C. Rowe, "Discovery of novel DNA gyrase inhibitors by high-throughput virtual screening," Antimicrobial Agents and Chemotherapy, vol. 51, no. 10, pp. 3688-3698, 2007.

[8] A. A. Al-Amiery, A. Kadhum, and A. Mohamad, "Antifungal activities of new coumarins," Molecules, vol. 17, no. 5, pp. 5713-5723, 2012.

[9] L. Koshy, B. S. Dwarakanath, H. G. Raj, R. Chandra, and T. Lazar Mathew, "Suicidal oxidative stress induced by certain antioxidants," Indian Journal of Experimental Biology, vol. 41, no. 11, pp. 1273-1278, 2003.

[10] K. C. Fylaktakidou, D. J. Hadjipavlou-Litina, K. E. Litinas, and D. N. Nicolaides, "Natural and synthetic coumarin derivatives with anti-inflammatory/antioxidant activities," Current Pharmaceutical Design, vol. 10, no. 30, pp. 3813-3833, 2004.

[11] M. Ghate, D. Manohar, V. Kulkarni, R. Shobha, and S. Y. Kattimani, "Synthesis of vanillin ethers from 4-(bromomethyl) coumarins as anti-inflammatory agents," European Journal of Medicinal Chemistry, vol. 38, no. 3, pp. 297-302, 2003.

[12] C. A. Kontogiorgis and D. J. Hadjipavlou-Litina, "Synthesis and antiinflammatory activity of coumarin derivatives," Journal of Medicinal Chemistry, vol. 48, no. 20, pp. 6400-6408, 2005.

[13] M. Baba, Y. Jin, A. Mizuno et al., "Studies on cancer chemoprevention by traditional folk medicines XXIV. Inhibitory effect of a coumarin derivative, 7-isopentenyloxycoumarin, against tumor-promotion," Biological and Pharmaceutical Bulletin, vol. 25, no. 2, pp. 244-246, 2002.

[14] D. Thornes, L. Daly, G. Lynch et al., "Prevention of early recurrence of high risk malignant melanoma by coumarin," European Journal of Surgical Oncology, vol. 15, no. 5, pp. 431-435, 1989.

[15] A. A. Al-Amiery, R. Al-Bayati, K. Saour, and M. Radi, "Cytotoxicity, antioxidant, and antimicrobial activities of novel 2quinolone derivatives derived from coumarin," Research on Chemical Intermediates, vol. 38, pp. 559-569, 2012. 
[16] A. Kadhum, A. Mohamad, A. A. Al-Amiery, and M. Takriff, "Antimicrobial and antioxidant activities of new metal complexes derived from 3-Aminocoumarin," Molecules, vol. 16, pp. 6969-6984, 2011.

[17] D. Završnik, S. Muratović, D. Makuc et al., "Benzylidenebis-(4-hydroxycoumarin) and benzopyrano-coumarin derivatives: synthesis, 1H/13C-NMR conformational and X-ray crystal structure studies and in vitro antiviral activity evaluations," Molecules, vol. 16, no. 7, pp. 6023-6040, 2011.

[18] S. Ali Beyramabadi and A. Morsali, "Intramolecular proton transfer of 2-[(2,4- dimethylphenyl)iminomethyl]-3,5-dimethoxyphenol schiff-base ligand: a density functional theory (DFT) study," International Journal of Physical Sciences, vol. 6, no. 7, pp. 1780-1788, 2011.

[19] M. Monajjemi, M. Sayadian, K. Zare, A. Ilkhani, and F. Mollaamin, "Computational study of hydrogen bonding on calix[8]arene as nanostructure compound," International Journal of Physical Sciences, vol. 6, no. 16, pp. 4063-4066, 2011.

[20] A. Kadhum, A. A. Al-Amiery, M. Shikara, and A. Mohamad, "Synthesis, structure elucidation and DFT studies of new thiadiazoles," International Journal of the Physical Sciences, vol. 6, no. 29, pp. 6692-6697, 2011.

[21] A. A. Al-Amiery, A. Musa, A. Kadhum, and A. Mohamad, "The use of umbelliferone in the synthesis of new heterocyclic compounds," Molecules, vol. 16, pp. 6833-6843, 2011.

[22] A. A. Al-Amiery, Y. K. Al-Majedy, H. Abdulreazak, and H. Abood, "Synthesis, characterization, theoretical crystal structure, and antibacterial activities of some transition metal complexes of the thiosemicarbazone (Z)-2-(pyrrolidin-2-ylidene) hydrazinecarbothioamide," vol. 2011, Article ID 483101, 6 pages, 2011.

[23] A. Kadhum, B. Wasmi, A. Mohamad, A. Al-Amiery, and M. Takriff, "Preparation, characterization, and theoretical studies of azelaic acid derived from oleic acid by use of a novel ozonolysis method," Research on Chemical Intermediates, vol. 38, pp. 659-668, 2011.

[24] A. H. Kadhum, A. A. Al-Amiery, A. Y. Musa, and A. Mohamad, "The antioxidant activity of new coumarin derivatives," International Journal of Molecular Sciences, vol. 12, pp. 5747-5576, 2011.

[25] A. A. Al-Amiery, A. Kadhum, and A. Mohamad, "Antifungal and antioxidant activities of pyrrolidone thiosemicarbazone complexes," Bioinorganic Chemistry and Applications, vol. 2012, Article ID 795812, 6 pages, 2012.

[26] A. A. Al-Amiery, Y. K. Al-Majedy, H. Ibrahim, and A. A. AlTamimi, "Antioxidant, antimicrobial,and theoretical studies of the thiosemicarbazone derivative Schiff base 2-(2-imino-1-methylimidazolidin-4-ylidene)hydrazinecarbothioamide (IMHC)," Organic and Medicinal Chemistry Letters, vol. 2, no. 4, 2012.

[27] R. I. H. Al-Bayati and M. F. Radi, "Synthesis of novel 2quinolone derivatives," African Journal of Pure and Applied Chemistry, vol. 4, no. 10, pp. 228-232, 2011.

[28] J. A. Pople et al., Gaussian, Inc., Wallingford CT, 2004 Gaussian 03W (Revision C.01), Gaussian, Inc., Wallingford CT, 2003.

[29] W. J. Pietro, M. M. Francl, W. J. Hehre, D. J. Defrees, J. A. Pople, and J. S. Binkley, "Self-consistent molecular orbital methods. 24. Supplemented small split-valence basis sets for second-row elements," Journal of the American Chemical Society, vol. 104, no. 19, pp. 5039-5048, 1982.
[30] K. D. Dobbs and W. J. Hehre, "Molecular orbital theory of the properties of inorganic and organometallic compounds 5. Extended basis sets for first-row transition metals," Journal of Computational Chemistry, vol. 8, pp. 861-879, 1987.

[31] A. D. Becke, "Density-functional exchange-energy approximation with correct asymptotic behavior," Physical Review Letters A, vol. 38, pp. 3098-3100, 1988.

[32] A. D. Becke, "Density-functional thermochemistry. III. The role of exact exchange," The Journal of Chemical Physics, vol. 98, no. 7, pp. 5648-5652, 1993.

[33] C. Lee, W. Yang, and R. G. Parr, "Development of the ColleSalvetti correlation-energy formula into a functional of the electron density," Review Letters B, vol. 37, no. 2, pp. 785-789, 1988.

[34] A. A. Al-Amiery, "Synthesis and antioxidant, antimicrobial evaluation, DFT studies of novel metal complexes derivate from Schiff base," Research on Chemical Intermediates, vol. 38, pp. 745-752, 2012.

[35] A. Musa, A. Mohamad, A. A. Al-Amiery, A. Kadhum, and L. Tien, "Galvanic corrosion of aluminum alloy (Al2024) and copper in 1.0 M hydrochloric acid solution," International Journal of Electrochemical Science, vol. 6, pp. 5052-5065, 2011. 


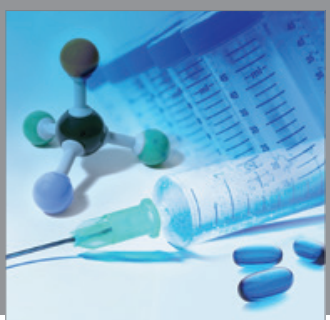

International Journal of

Medicinal Chemistry

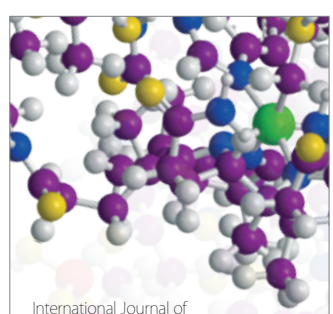

Carbohydrate Chemistry

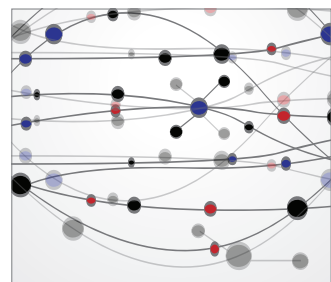

The Scientific World Journal
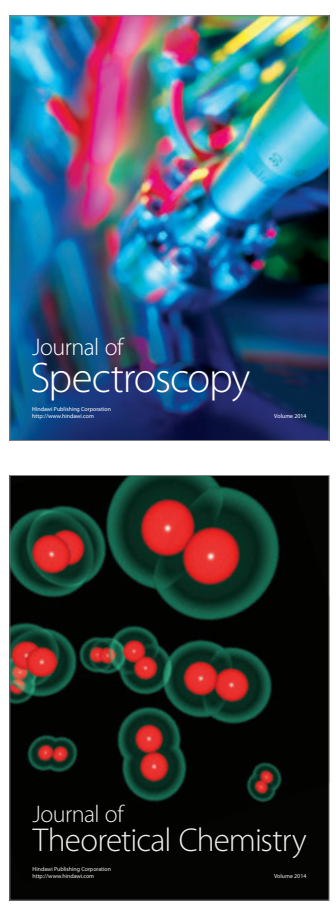
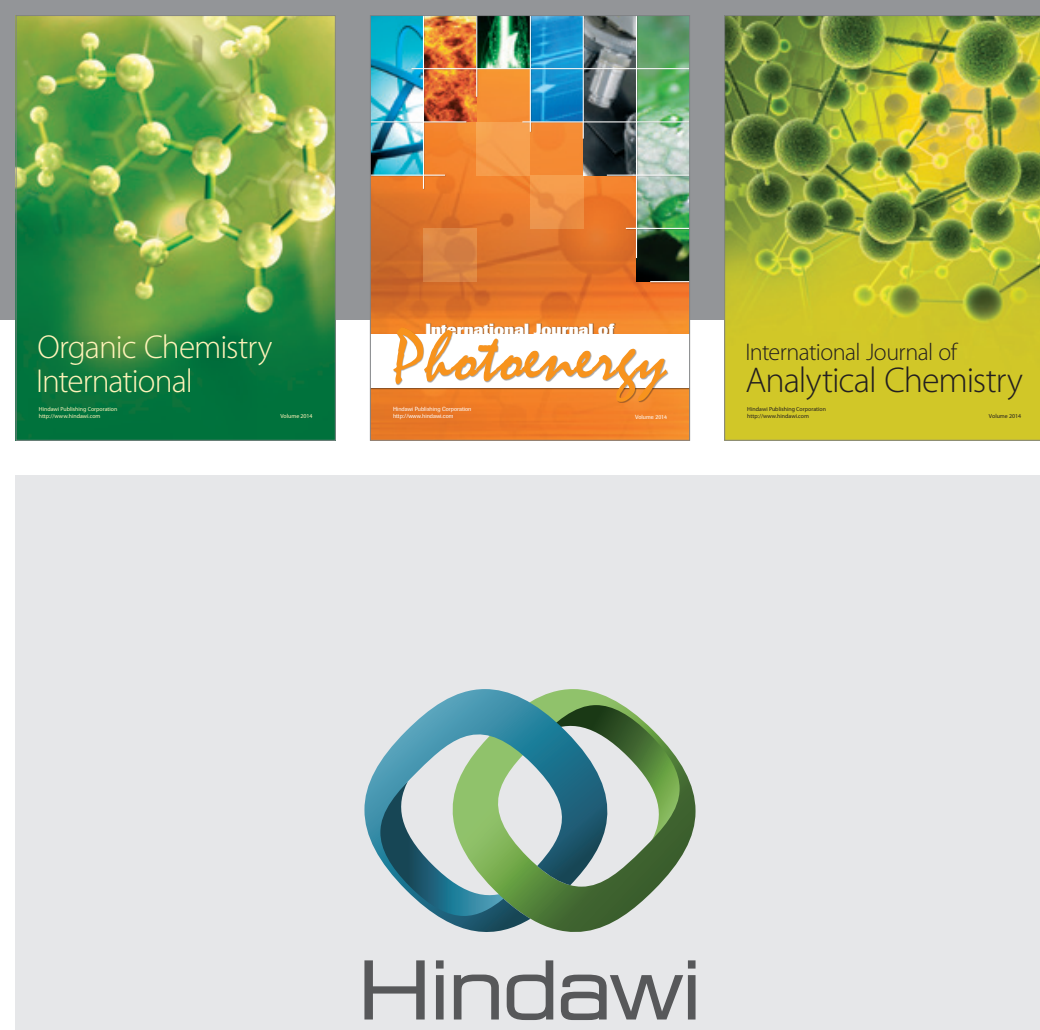

Submit your manuscripts at

http://www.hindawi.com
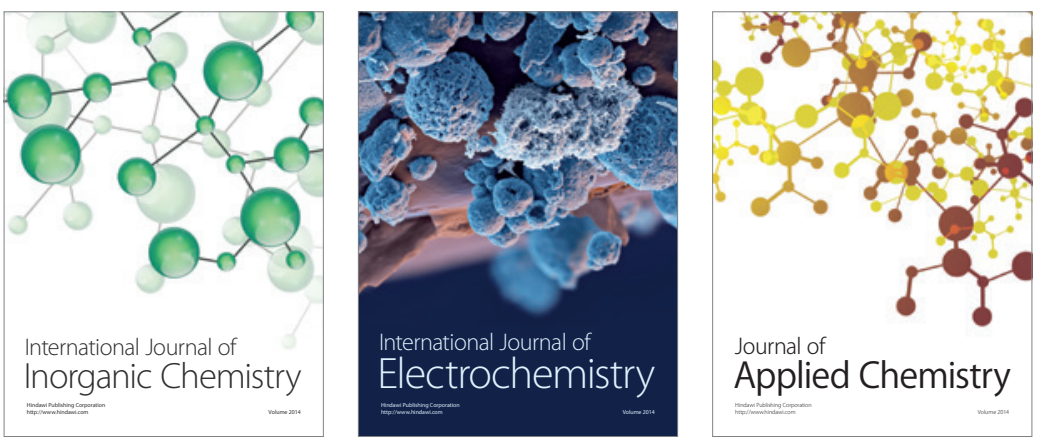

Journal of

Applied Chemistry
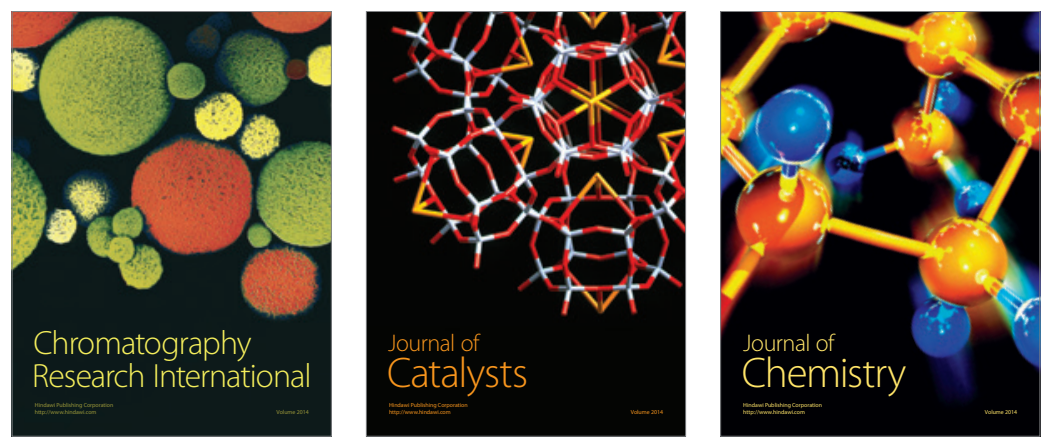
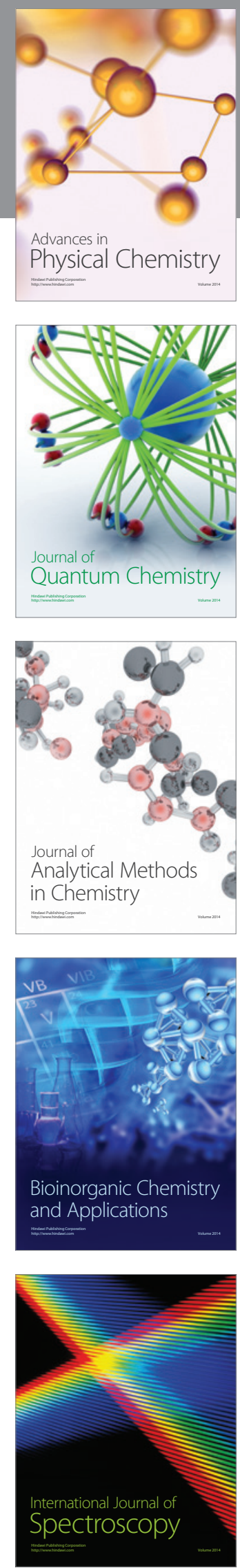